\title{
Yoan Vérilhac, La jeune critique des petites revues symbolistes
}

Ida Merello

\section{(2) OpenEdition}

1 Journals

\section{Edizione digitale}

URL: http://journals.openedition.org/studifrancesi/5734

DOI: 10.4000/studifrancesi.5734

ISSN: 2421-5856

Editore

Rosenberg \& Sellier

\section{Edizione cartacea}

Data di pubblicazione: 1 septembre 2011

Paginazione: 449

ISSN: 0039-2944

\section{Notizia bibliografica digitale}

Ida Merello, «Yoan Vérilhac, La jeune critique des petites revues symbolistes», Studi Francesi [Online], 164 (LV | II) | 2011, online dal 30 novembre 2015, consultato il 13 janvier 2021. URL: http://

journals.openedition.org/studifrancesi/5734 ; DOI: https://doi.org/10.4000/studifrancesi.5734

Questo documento è stato generato automaticamente il 13 janvier 2021.

\section{(c) (i) (9)}

Studi Francesi è distribuita con Licenza Creative Commons Attribuzione - Non commerciale - Non opere derivate 4.0 Internazionale. 
Yoan Vérilhac, La jeune critique des petites revues symbolistes

Ida Merello 


\section{NOTIZIA}

YOAN VÉRILHAC, La jeune critique des petites revues symbolistes, Saint-Etienne, Presses

Universitaires de St-Etienne, 2010, 339 pp.

1 L'A. tenta di individuare le caratteristiche della critica militante delle "petites revues symbolistes», ossia di quelle riviste brevi ed effimere che tendono a connotarsi anche per un carattere "giovanile», vale a dire non accademico e antiufficiale. Prescinde tuttavia da una discesa in profondità nel tessuto connettivo del periodo, accontentandosi di generalizzazioni (per una definizione del simbolismo cita l'Encyclopédia universalis e il Dictionnaire égoïste di Charles Dantzig), e cadendo quindi in affermazioni del tipo «René Ghil est digne d'analyses sérieuses...». Analogamente non offre una ricognizione esaustiva del materiale - limitato invece a pochi titoli. Isola comunque un primo periodo, in cui ogni rivista rivendica la propria autonomia e presenta la propria estetica (che non è tuttavia l'oggetto del suo interesse), e un secondo, con inizio nel 1888-1889, in cui vede affermarsi una diversa solidarietà, per la presenza all'interno di ciascuna rivista di una «revue des revues» e l'auspicio generale di un giornale comune. Nel frattempo si preciserebbe sempre più una formula di composizione della «petite revue» che diventerebbe il modello comune di riferimento. L'A. procede quindi a un'analisi del carattere della critica delle "petites revues», sia dal punto di vista ideologico (parzialità, intolleranza, dogmatismo ecc.) che da quello tecnico di scrittura (impiego di diversi strumenti retorici), mostrando la duplice funzione critica e autoriale degli scrittori e dei poeti.

Discutibile la scelta di far seguire il testo da cenni bio-bibliografici su autori come Adam, Kahn, Régnier, e persino Remy de Gourmont. Il volume è corredato da una bibliografia molto essenziale. 